\title{
Soil organic carbon dynamics along a climatic gradient in a southern Appalachian spruce-fir forest
}

\author{
C.E. Tewksbury and H. Van Miegroet
}

\begin{abstract}
A field study was conducted in a high-elevation spruce-fir (Picea rubens Sarg. - Abies fraseri (Pursh.) Poir) forest in the Great Smoky Mountains National Park to assess the effect of temperature on soil C storage and dynamics. In eight plots along an elevation gradient (1500-1900 m), we measured soil temperature, forest floor and mineral soil C, litter decomposition, soil respiration, and forest floor mean residence time. Mean annual soil temperature and annual degreedays above $5{ }^{\circ} \mathrm{C}$ were inversely correlated with elevation. Total soil C (166-241 Mg.ha ${ }^{-1}$ ) showed no trend with elevation, while forest floor $\mathrm{C}$ accumulation (16.3-35.9 $\mathrm{Mg} \cdot \mathrm{ha}^{-1}$ ) decreased significantly with elevation. Carbon dynamics did not follow a consistent elevation pattern; however, the cooler upper elevations showed the lowest $\mathrm{C}$ turnover as indicated by the lowest needle decomposition rate $\left(k=0.0231 \cdot \mathrm{year}^{-1}\right)$ and the longest mean residence time of forest floor $\mathrm{C}(22$ years). Mean annual $\mathrm{CO}_{2}$ efflux from the soil $\left(1020-1830 \mathrm{~kg} \mathrm{C} \cdot \mathrm{ha}^{-1} \cdot \mathrm{year}^{-1}\right)$ was negatively correlated with mean annual soil temperatures and annual degree-days above $5{ }^{\circ} \mathrm{C}$. This gradient study offers useful insights into $\mathrm{C}$ release patterns under future warming scenarios, and suggests that the highest elevation may be most susceptible to global warming.

Résumé : Une étude de terrain a été entreprise dans une forêt en haute altitude composée d'épinette et de sapin (Picea rubens Sarg. et Abies fraseri (Pursh.) Poir) située dans le parc national de Great Smoky Mountains pour évaluer l'effet de la température sur l'entreposage et la dynamique du C dans le sol. Dans huit parcelles établies le long d'un gradient altitudinal (1500 à 1900 m), nous avons mesuré la température du sol, la teneur en C de la couverture morte et du sol minéral, la décomposition de la litière, la respiration du sol et le temps de résidence moyen de la couverture morte. La température annuelle moyenne du sol et le nombre de degrés-jours au-dessus de $5{ }^{\circ} \mathrm{C}$ étaient inversement corrélés à l'altitude. La teneur totale en $\mathrm{C}$ du sol (166 à $241 \mathrm{Mg} \cdot \mathrm{ha}^{-1}$ ) n'a montré aucune tendance avec l'altitude alors que l'accumulation de C dans la couverture morte (16,3 à 35,9 Mg·ha $\left.{ }^{-1}\right)$ diminuait de façon significative avec l'altitude. La dynamique du carbone ne suivait pas un patron altitudinal cohérent. Cependant, les températures froides des altitudes plus élevées étaient associées à un plus faible taux de renouvellement du $\mathrm{C}$ comme l'indiquent le taux de décomposition des aiguilles le plus faible $(k=$ $0,0231 \cdot \mathrm{an}^{-1}$ ) et le temps de résidence moyen du $\mathrm{C}$ de la couverture morte le plus long (22 ans). Le débit annuel moyen de $\mathrm{CO}_{2}$ en provenance du sol (1020 à $\left.1830 \mathrm{~kg} \mathrm{C} \cdot \mathrm{ha}^{-1} \cdot \mathrm{an}^{-1}\right)$ était négativement corrélé à la température annuelle moyenne du sol et au nombre de degrés-jours au-dessus de $5{ }^{\circ} \mathrm{C}$. Cette étude de gradient donne un aperçu utile des patrons de libération de $\mathrm{C}$ en fonction de scénarios futurs de réchauffement et indique que les altitudes élevées peuvent être davantage affectées par le réchauffement global.
\end{abstract}

[Traduit par la Rédaction]

\section{Introduction}

In the coming century, atmospheric concentrations of $\mathrm{CO}_{2}$ are expected to double, and global average temperature may increase by 1.8 to $5.8{ }^{\circ} \mathrm{C}$ (Albritton et al. 2001). Admundson (2001) postulates that any increase in global temperatures will undoubtedly affect soil organic carbon (SOC) storage. Global $\mathrm{C}$ reserves in soils are large, so small changes in SOC storage may significantly affect atmospheric $\mathrm{CO}_{2}$ concentrations (Kirschbaum 2000). However, both the direction and magnitude of the feedbacks between SOC and atmospheric $\mathrm{CO}_{2}$ remain subject to substantial uncertainties. Davidson and Janssens (2006) suggest that much of soilmediated feedback between climate change and the global
C cycle will greatly depend on the temperature sensitivity of decomposition.

Liski et al. (1999) and Giardina and Ryan (2000) have postulated that only decomposition of young litter and labile $\mathrm{C}$ (i.e., forest floor) accelerates with increasing temperature, while older, more stable $\mathrm{C}$ in the mineral soil is far less responsive to temperature changes. Subsequent studies have refuted this assertion, and have provided evidence that even relatively resistant SOC pools are temperature sensitive (Knorr et al. 2005).

A meta-analysis of 32 ecosystem warming experiments indicates that higher soil temperatures stimulate $\mathrm{CO}_{2}$ emission from soils (Rustad et al. 2001). Yet, concurrent in-

Received 17 April 2006. Accepted 30 November 2006. Published on the NRC Research Press Web site at cjfr.nrc.ca on 1 August 2007.

C.E. Tewksbury ${ }^{1}$ and H. Van Miegroet. ${ }^{2}$ Utah State University, Department Wildland Resources, 5230 Old Main Hill, Logan, UT 84322-5230, USA.

${ }^{1}$ Present address: University of Arizona, School of Natural Resources, 325 Biological Sciences East, Tucson, AZ 85721-0043, USA.

${ }^{2}$ Corresponding author (e-mail: helgavm@cc.usu.edu). 
creases in nutrient availability and higher atmospheric $\mathrm{CO}_{2}$ levels may enhance net primary productivity and $\mathrm{C}$ input to the soils (Kirschbaum 1995; Melillo et al. 2002), possibly counteracting the soil response (Kirschbaum 2000). An increase in soil $\mathrm{C}$ storage due to accelerated net primary productivity is limited by the extent to which $\mathrm{C}$ additions are partitioned into pools with slow turnover rates (Trumbore 2000; Schlesinger and Lichter 2001).

Temperate and boreal forest ecosystems have relatively large reservoirs of organic $\mathrm{C}$ in the form of forest floors (Post et al. 1982; Vogt et al. 1996). Some have suggested that soil respiration rates are generally more responsive to warming than productivity in these cool, high-latitude ecosystems (Schleser 1982; Kirschbaum 1995). Although the quality and quantity of inputs affect the storage of $\mathrm{C}$ in forest floor, abiotic factors controlling $\mathrm{C}$ loss may be more important in determining $\mathrm{C}$ storage in temperate ecosystems (Simmons et al. 1996; Vogt et al. 1996). Cool climate forest ecosystems are expected to experience the largest and earliest effects of warming (Zolbrod and Peterson 1999; Prichard et al. 2000). Considering current evidence, these ecosystems may represent significant net sources of $\mathrm{CO}_{2}$ to the atmosphere.

The cool temperate, high-elevation red spruce - Fraser fir (Picea rubens Sarg. - Abies fraseri (Pursh.) Poir) forests in the southern Appalachians are an example of coniferous forests with large accumulations of organic $\mathrm{C}$ in the forest floor and surface soil horizons. Although the geographic extent of this forest type is relatively small, $\sim 27000$ ha, $\sim 74 \%$ of which occurs in the Great Smoky Mountain National Park (GSMNP) (Dull et al. 1988), the spruce-fir forest occupies a unique area of forest soil types within the southeastern United States (Fernandez 1992). Steepness of the terrain and difficulties in access has limited much soils research in this forest type (Bolstad and Vose 2001; Miller et al. 2004). The majority of this area has not experienced severe, standreplacing disturbances such as fire or logging (Pyle and Schafale 1988). The prevalence of old unglaciated landscapes with a legacy of soil $\mathrm{C}$ and limited fire history (Pyle and Schafale 1988) has resulted in significant $C$ accumulation in soils (Johnson et al. 1991; Joslin et al. 1992) and aboveground biomass (Van Miegroet et al. 2007). More recently, the spruce-fir forest has been impacted by the balsam wooly adelgid (Adelges piceae (Ratz.)) (BWA), causing dieback of mature Fraser fir and spatial heterogeneity of coarse woody debris on the forest floor (Nicholas et al. 1992; Rose 2000). Because the spruce-fir forest type is at the southern edge of its distribution occupying the highest and coolest available mountain ranges; and because large pools of organic matter in the forest floor and upper mineral horizons have developed under a cool, moist temperate climatic regime; this ecosystem may be particularly sensitive to climatic warming. Garten et al. (1999) predicted substantial losses $(\sim 42 \%-46 \%)$ of organic C from high-elevation spruce-fir soils under future regional warming scenarios, especially since a high proportion of $\mathrm{C}$ in these forest soils is thought to be associated with unprotected pool or labile organic matter, highly susceptible to enhanced mineralization with increase in temperature (Garten et al. 1999, 2000).

This research focuses on the mature high-elevation sprucefir forest type in the GSMNP, because it presents the opportunity to study the influence of climate on storage and dynamics of soil $\mathrm{C}$ in a distinctive and highly valued forest in the southern Appalachians that may be particularly sensitive to climate-induced changes in ecosystem structure and function. The objectives of this study were to quantify and characterize soil organic $\mathrm{C}$ storage and dynamics along an elevation gradient of the spruce-fir zone within the GSMNP, with elevation as a predicted surrogate for temperature. It was predicted: $(i)$ that a significant negative correlation would exist between elevation and temperature; and (ii) that the different temperature regimes along the elevation gradient would result in a predictable trend in SOC storage and dynamics, with lower soil $\mathrm{C}$ storage and faster $\mathrm{C}$ turnover at lower elevations characterized by a warmer climate, and slower turnover and larger $\mathrm{C}$ storage in upper elevations characterized by a cooler climate. The warmer conditions in the lower elevations of this gradient study may give indications of how future climatic trajectories may affect soil $\mathrm{C}$ processes at higher elevations.

\section{Materials and methods}

\section{Study site}

The study was conducted in the high-elevation spruce-fir zone of GSMNP in the proximity of Clingman's Dome, on the North Carolina and Tennessee border. It capitalized on existing infrastructure and available data from prior and ongoing research on forest dynamics (Nicholas et al. 1992), nutrient cycling (Johnson et al. 1991), soil processes (Garten and Van Miegroet 1994), and watershed dynamics (Nodvin et al. 1995; Van Miegroet et al. 2001) in high-elevation spruce-fir forests. This is an uneven-aged forest, with red spruce and Fraser fir as the dominant overstory species. Species distribution follows an elevational gradient. The overstory is dominated by mature red spruce in the lower elevations (1370-1650 m), and the understory consists mainly of hardwoods including yellow birch (Betula lutea Michaux f.), mountain ash (Sorbus americana Marshall), and mountain maple (Acer spicatum Lam.). At middle elevations (1675-1890 m), red spruce and Fraser fir codominate. At higher elevations ( $>1890 \mathrm{~m})$, the forest has undergone canopy decline because of Fraser fir mortality caused by the infestation of the BWA and the overstory is dominated by young and standing dead Fraser fir with a component of red spruce (Nicholas et al. 1992; Pauley et al. 1996).

The soils are Inceptisols with spodic characteristics classified as Dystrochrepts or Haplumbrepts, typified by relatively thick O-horizons $(5-10 \mathrm{~cm})$ that overlie organic matter rich A-horizons (Kelly and Mays 1989; Joslin et al. 1992; Van Miegroet et al. 1993). Soils are underlain by Thunderhead sandstone of the Great Smoky Group (King and Stupka 1950; Feldman et al. 1991). They are relatively shallow with estimates of total depth ranging from $\sim 50 \mathrm{~cm}$ (Van Miegroet et al. 2001) to $\sim 60-65 \mathrm{~cm}$ (Johnson and Lindberg 1992) and have a silt loam to sandy loam texture. Despite the relatively old landscapes that dominate the southeastern US, the soils in this ecosystem are genetically young and developmentally immature because of slope instability and soil mixing associated with frequent landslides on steeper slopes and windthrow of shallow-rooted trees (Wolfe 1967; Fernandez 1992; White and Cogbill 1992). Soils are acidic, characterized by high organic matter content and low base 
saturation, as well as high nitrogen (N) mineralization and nitrification capacity (Johnson et al. 1991; Garten and Van Miegroet 1994).

Mean annual temperature at the study site is $8.5^{\circ} \mathrm{C}$, ranging from $-2{ }^{\circ} \mathrm{C}$ in January to $18{ }^{\circ} \mathrm{C}$ in July, with a frost-free period from May through September (Johnson et al. 1991). Mean annual precipitation is $230 \mathrm{~cm}$, with annual variations of $150-300 \mathrm{~cm}$, with $10 \%$ as snow (Van Miegroet et al. 2001). Precipitation generally exceeds evapotranspiration (Shanks 1954), although some moisture stress occurs in summer and early fall (Pauley 1989). These climatic conditions result in a relatively short growing season (100-150 days), combined with frequent cloud immersion and high winds (White and Cogbill 1992; Johnson et al. 1991).

\section{Experimental design}

The core measurements were conducted in selected plots in the Noland Divide Watershed (NDW), a small (17.4 ha), high-elevation (1700-1900 m) forested catchment, and from an adjacent network of plots established in the mid-1980s as part of the National Acid Precipitation Assessment Program (NAPAP) (Nicholas et al. 1992). To encompass the full spruce-fir elevation range within the GSMNP (Nicholas et al. 1992), eight $20 \mathrm{~m} \times 20 \mathrm{~m}$ plots were included in our design: four NAPAP plots, two above NDW at an elevation of 2000 m near Clingman's Dome, and two below the catchment outlet at an elevation of $\sim 1530 \mathrm{~m}$; and four plots within the NDW, two in the upper catchment at $\sim 1850 \mathrm{~m}$, and two in the lower catchment at $\sim 1700 \mathrm{~m}$ ("intensive plots", Fig. 1). Selection criteria for the eight plots were as follows: stratification along the full elevation range of the spruce-fir forest within the GSMNP (1450-2000 m); proximity to one another and similar aspect (east) to minimize possible differences in geology and climate; relatively intact forest structure to minimize the confounding effect of recent gaps on soil microclimate and $\mathrm{C}$ dynamics; and overstory species composition and live basal area (LBA) representative of that particular elevation band (Nicholas et al. 1992). Some plot characteristics are summarized in Table 1.

\section{Soil temperature}

Stowaway Tidbit dataloggers (Onset Computer Corporation, Pocasset, Massachusetts) were placed at $\sim 10 \mathrm{~cm}$ soil depth in the center of each plot and programmed to measure soil temperature every $2 \mathrm{~h}$ over a 2 year period (20012003). Mean annual soil temperatures were calculated as the average of the minimum and maximum daily temperature readings during the year. An annual soil heat index was expressed as annual soil degree-days (ADD) and calculated as the sum of mean daily soil temperatures above $5{ }^{\circ} \mathrm{C}$ over the year. Five degrees and higher was chosen as a threshold for microbial activity (Alexander 1977). Additional soil temperature readings for the NDW were obtained between 1998 and 2003 using dataloggers placed along a central elevation transect $(\mathrm{H}$. Van Miegroet, unpublished data) ("temperature transect", Fig. 1).

\section{Soil organic carbon pools}

Carbon content of the forest floor (Oi, Oa, and Oe) in the plots was determined in October 2003 by excavating a $15 \mathrm{~cm} \times 15 \mathrm{~cm}$ area at four random locations at the periph- ery of each plot using a sampling frame. All samples were oven-dried $\left(65{ }^{\circ} \mathrm{C}\right)$, weighed, ground in a Wiley mill (No. 40 mesh screen; $0.85 \mathrm{~mm}$ mesh), and subsamples were analyzed for $\mathrm{C}$ concentration using a LECO $\mathrm{CN}$ analyzer (CHN 1000; Leco Corp., St. Joseph, Michigan).

Mineral soil cores were taken at four locations at the periphery of each plot in summer 2004 and were sampled from $0-15 \mathrm{~cm}$ and then in $10 \mathrm{~cm}$ sections to a depth of $50 \mathrm{~cm}$ or until bedrock. The $0-15 \mathrm{~cm}$ section represented a combination of O- and A-horizons; therefore, the organic horizon was removed and only the mineral soil was further analyzed. Because mineral soils were high in organic matter, all samples were oven-dried at $65{ }^{\circ} \mathrm{C}$, which is appropriate for organicrich substrates, sieved ( $2 \mathrm{~mm}$ mesh), and homogenized with a mortar and pestle, composited per depth increment and plot, and analyzed for total $\mathrm{C}$ on a LECO $\mathrm{CN}$ analyzer. Bulk density and percent gravel for mineral soil was determined using the core method (Blake and Hartge 1986) in the eight plots (four replicate cores per plot). In addition to these mineral and forest floor estimates, ecosystem overstory and coarse woody debris pools were determined as part of the larger C budget project (Van Miegroet et al. 2007).

\section{Soil organic carbon dynamics}

To analyze the effects of temperature on organic $\mathrm{C}$ dynamics, we quantified the turnover of various SOC cohorts. We measured litter decomposition rates as an indicator of the turnover of a single cohort of needle fall; mean residence time of forest floor $\mathrm{C}$ pools as a indicator of the dynamics of a mixed organic layer cohort; and $\mathrm{CO}_{2}$ efflux rates from the soil as an indicator of total belowground $\mathrm{C}$ dynamics.

\section{Litter decomposition rates}

Litter decomposition rates were determined from litterbags with a homogeneous substrate of air-dried spruce needles, obtained earlier from littertraps and fallen trees. Using the same substrate across all plots allowed us to explicitly test the influence of soil microclimate on litter decomposition without the confounding effect of litter chemical composition. Litterbags $(17 \mathrm{~cm} \times 17 \mathrm{~cm})$ were constructed using fine sport utility nylon on the bottom and $1 \mathrm{~mm}$ mesh cloth on the top, allowing access by invertebrate decomposers without losing sample from the bottom. All litterbags, containing approximately $15 \mathrm{~g}$ of initial air-dried litter, were assembled, weighed, transported to the field in individual plastic bags, and anchored into the forest floor at random locations (30 bags per plot; 240 bags total) in May of 2002. The mass of needles lost from the litterbags in transport and collected in the plastic bags was subtracted from the initial substrate mass. At 6, 12, 18, 24, and 36 months (October 2002 - June 2005), five litterbags were collected from each plot, oven-dried at $65{ }^{\circ} \mathrm{C}$ until thoroughly dried, and litter remaining was weighed. Subsamples were ground with a Wiley mill (No. 40 mesh screen, $0.85 \mathrm{~mm}$ mesh) and analyzed for $\mathrm{C}$ using a LECO CN analyzer. Litter C concentrations were corrected for ash content via loss-on-ignition, to account for possible contamination of the litter samples with mineral soil.

\section{Forest floor mean residence time}

In addition to the forest floor measurements described 
Fig. 1. Map of study site and plot layout in the Great Smoky Mountains National Park.

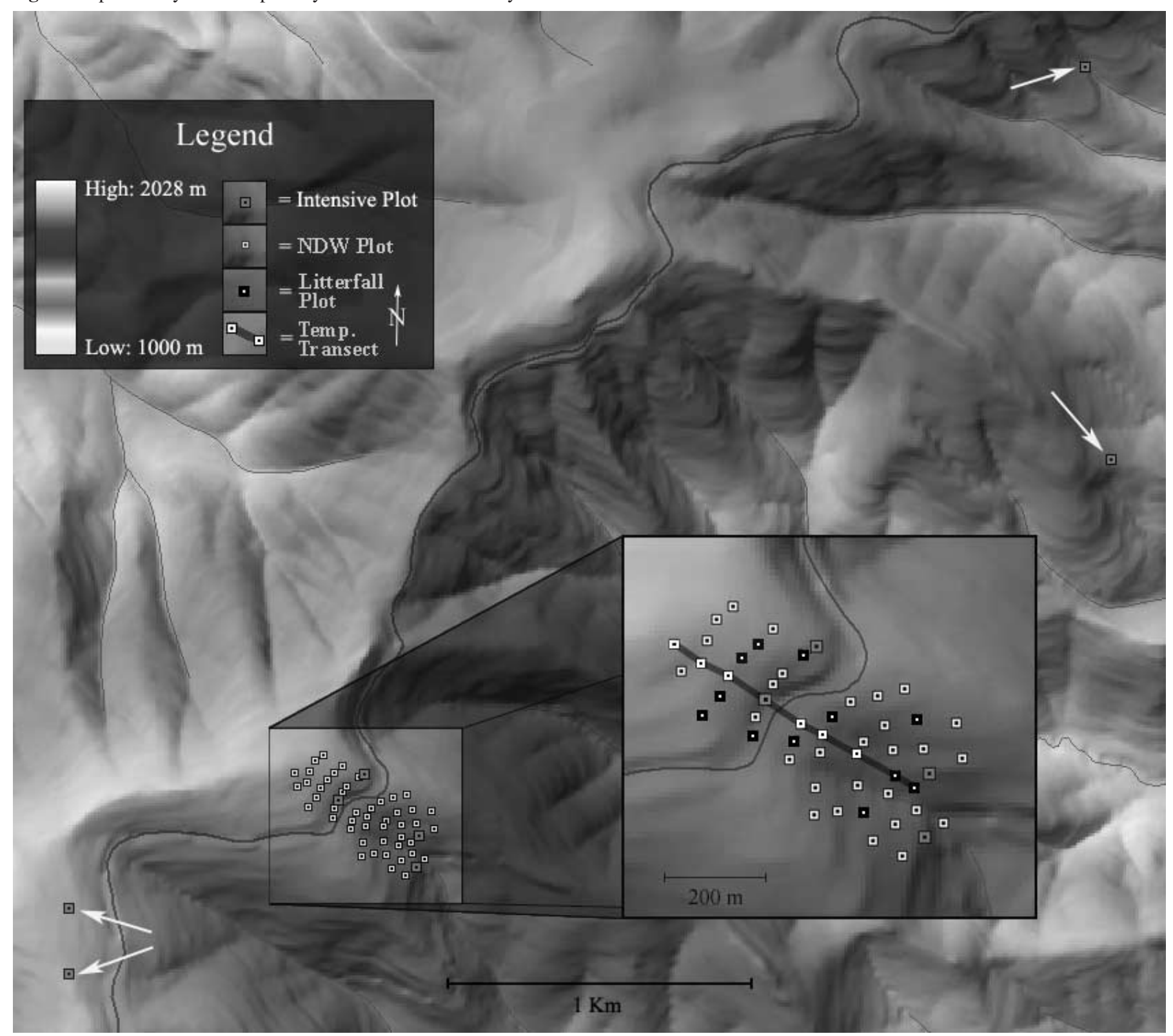

Table 1. Spruce-fir plot characteristics.

\begin{tabular}{|c|c|c|c|c|c|c|c|}
\hline Plot & $\begin{array}{l}\text { Elevation } \\
(\mathrm{m})\end{array}$ & Elevation band $(\mathrm{m})$ & Aspect & Slope $(\%)$ & $\begin{array}{l}\text { Live basal } \\
\text { area }\left(\mathrm{m}^{2} \cdot \mathrm{ha}^{-1}\right)\end{array}$ & $\begin{array}{l}\text { Mean annual soil } \\
\text { temperature }\left({ }^{\circ} \mathrm{C}\right)\end{array}$ & $\begin{array}{l}\text { Annual degree-days } \\
\text { (days) }\end{array}$ \\
\hline 1 & 1524 & Lower $(\sim 1550)$ & SE & 40 & 60.9 & 8.86 & 1660 \\
\hline 2 & 1536 & & $\mathrm{E}$ & 45 & 59.2 & 9.29 & 1756 \\
\hline 3 & 1701 & Lower-mid $(\sim 1700)$ & E & 49 & 36.6 & 7.89 & 1430 \\
\hline 4 & 1701 & & $\mathrm{~S}$ & 50 & 41.4 & 7.34 & 1263 \\
\hline 5 & 1835 & Upper-mid $(\sim 1850)$ & SE & 40 & 49.0 & 7.01 & 1283 \\
\hline 6 & 1835 & & SE & 40 & 63.0 & 8.97 & 1695 \\
\hline 7 & 1966 & Upper $(\sim 2000)$ & $\mathrm{NE}$ & 27 & 38.7 & 5.64 & 1064 \\
\hline 8 & 1966 & & E & 27 & 53.5 & 6.91 & 1180 \\
\hline Overall mean & & & & & & 7.74 & 1417 \\
\hline
\end{tabular}

earlier, forest floor C content of 12 NDW plots was calculated from dry mass measurements from four replicate cores (inside diameter $4.1 \mathrm{~cm}$ ) per plot taken in summer 1998 and
1999, as part of another study initiated earlier in the NDW (H. Van Miegroet, unpublished data). The plots were located along three elevation bands composed of four plots each 
(low, 1705-1768 m; medium, 1798-1828 m; and high, $1859-1920 \mathrm{~m}$ ) representing the elevation range of the watershed (Barker et al. 2002) (Fig. 1). Litterfall was collected in the four NAPAP plots and the $12 \mathrm{NDW}$ plots ("litterfall plots", Fig. 1) using round litterfall collection traps $\left(0.07 \mathrm{~m}^{2}\right)$ located at the four corners of the plot quadrants. Samples were collected from each of the four NAPAP plots in May, August, October for 2 years (2001-2003), and for the NDW during the same months over 5 years (19982003) as part of another study (Barker et al. 2002). All samples were oven-dried at $65{ }^{\circ} \mathrm{C}$ and weighed; composited by plot; sorted into four fractions: (1) needles, (2) foliage, (3) twigs and bark, and (4) other; ground in a Wiley mill (No. 40 mesh screen; $0.85 \mathrm{~mm}$ mesh); and analyzed for $\mathrm{C}$ using a LECO CN analyzer. In this study, mean residence time (MRT) of forest floor $\mathrm{C}$ was calculated for the four NAPAP plots and $12 \mathrm{NDW}$ plots as

$$
\begin{aligned}
& \operatorname{MRT}(\text { years })=\text { Forest floor } \mathrm{C} \text { biomass }\left(\mathrm{kg} \mathrm{C} \cdot \mathrm{ha}^{-1}\right) \\
& \text { /annual litterfall }\left(\mathrm{kg} \mathrm{C} \cdot \mathrm{ha}^{-1} \cdot \text { year }^{-1}\right)
\end{aligned}
$$

Data for the NDW plots are presented as means by elevation band $(n=4)$, using average elevation within each band in the analysis of elevation patterns.

\section{Soil respiration}

Soil respiration was measured in summer and fall in the eight plots over a 2 year period for a total of 10 measurements between May 2002 and May 2004. At four locations in each plot, $\mathrm{CO}_{2}$ efflux from the soil surface was measured over a $24 \mathrm{~h}$ period using the static chamber technique with $2 \mathrm{~mol} \cdot \mathrm{L}^{-1} \mathrm{NaOH}$ as the trapping agent (Cropper et al. 1985; Raich et al. 1990), followed by back titration with $0.75 \mathrm{~mol} \cdot \mathrm{L}^{-1} \mathrm{HCl}$ in the laboratory. Soil respiration measurements were not taken during the winter because of limited accessiblity, and average daily winter respiration rates were estimated for each plot from measured summer rates and average soil temperatures using the equation (Zak et al. 1993)

$$
k_{1}=k_{2} \quad \mathrm{e}^{\left(t_{1}-t_{2}\right) / 10 \times \ln Q_{10}}
$$

where $k_{1}$ is calculated daily winter respiration rate, $k_{2}$ is mean measured daily summer respiration rate, $t_{1}$ is average winter soil temperature, $t_{2}$ is average summer soil temperature, and $Q_{10}=2$. Data were organized into three periods: summer, 15 May - 31 August; fall, 1 September - 15 November; winter, 15 November - 15 May. For each period, average daily respiration rate was multiplied by the number of days (summer, $107 \mathrm{~d}$; fall, $76 \mathrm{~d}$; winter, $181 \mathrm{~d}$ ), and annual $\mathrm{CO}_{2}$ emission from the soil was calculated as the sum of the seasonal values.

\section{Statistical analysis}

We used linear regression to analyze relationships between the response variables (soil $\mathrm{C}$ pools and dynamics) and indices of temperature regime, represented by the elevation gradient in this study. In some of the linear regression analyses, data were analyzed by elevation band with two plot replicates per band. Litter decomposition data were analyzed using one-way ANOVA to test significant differences in decomposition rates with time followed by a $t$ test (LSD,
Fig. 2. Relationship between mean annual soil temperature and elevation across the eight plots.

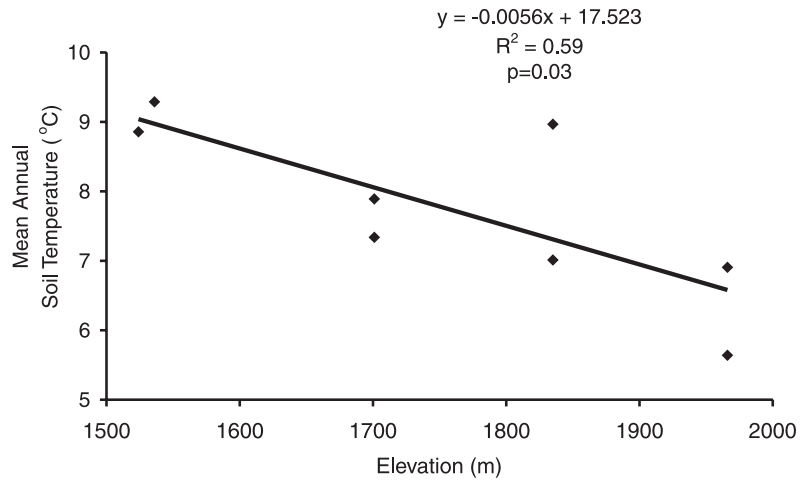

least significant difference) to determine significant differences between the elevation bands. The decomposition of litter was also described by a simple single-exponential decay model

$$
X_{t}=X_{0} \mathrm{e}^{-k t}
$$

where $X_{0}$ is the initial mass of litter, $X_{t}$ is the mass of litter at time $t$, and $k$ is the decay rate constant (Olson 1963; Swift et al. 1979). Decay constants for each elevation band were derived from all decomposition data for the 3 year period using curve-fitting nonlinear regression. Multiple linear regression was used to investigate the effects of independent climate variables on respiration rates. We considered model parameters to be significant if: $R^{2} \geq 0.40$ and $p \leq 0.1$. All data were analyzed using SAS (version 8.1 edition, SAS Institute, Inc. 2002).

\section{Results and discussion}

\section{Elevation and soil temperature}

Plot differences in soil temperature regime are summarized in Table 1. Mean annual soil temperature (MAST) across the eight spruce-fir plots was $7.7{ }^{\circ} \mathrm{C}$ at $10 \mathrm{~cm}$ soil depth, similar to the value of $7.4{ }^{\circ} \mathrm{C}$ at $10 \mathrm{~cm}$ soil depth reported by Garten et al. (1999) for two nearby high-elevation spruce-fir sites. Average annual soil temperatures ranged from $5.6{ }^{\circ} \mathrm{C}$ in the upper elevations to $9.3{ }^{\circ} \mathrm{C}$ in the lower elevations, with corresponding annual degree-days (ADD) above $5{ }^{\circ} \mathrm{C}$ ranging from 1064 to 1756 (Table 1). There was a significant negative correlation between elevation and MAST (Fig. 2), corresponding to a mean lapse rate of $0.56{ }^{\circ} \mathrm{C}$ per $100 \mathrm{~m}$ rise in elevation. The calculated soil heat index (ADD) was also negatively correlated with elevation $\left(R^{2}=0.56, p=0.03 ; y=-1.118 x+3382\right)$. These results confirmed our assertion that elevation could serve as a proxy for temperature in our experimental design, which allowed for investigation of the effect of temperature on $\mathrm{C}$ dynamics.

\section{Soil organic carbon pools}

Total ecosystem $\mathrm{C}$ storage across the plots was approximately $400 \pm 87 \mathrm{Mg} \cdot \mathrm{ha}^{-1}$. Overstory biomass averaged

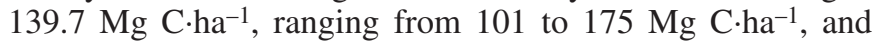
represented $36 \%$ of total ecosystem C storage. Coarse woody debris averaged $38.5 \mathrm{Mg} \mathrm{C} \cdot \mathrm{ha}^{-1}$ or $10 \%$ of total ecosystem C storage, but was highly variable, ranging from 2.6 
Table 2. Total organic carbon storage in spruce-fir soils to a depth of $50 \mathrm{~cm}$.

\begin{tabular}{|c|c|c|c|c|c|}
\hline Plot & Elevation (m) & $\begin{array}{l}\text { Forest floor (O-horizon) } \\
\left(\mathrm{Mg} \mathrm{C} \cdot \mathrm{ha}^{-1}\right)\end{array}$ & 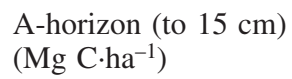 & $\begin{array}{l}\text { Mineral soil }(15-50 \mathrm{~cm}) \\
\left(\mathrm{Mg} \mathrm{C} \cdot \mathrm{ha}^{-1}\right)\end{array}$ & $\begin{array}{l}\text { Total }(0-50 \mathrm{~cm}) \\
\left(\mathrm{Mg} \mathrm{C} \cdot \mathrm{ha}^{-1}\right)\end{array}$ \\
\hline 1 & 1524 & 25.1 & 30.1 & 152.1 & 207.3 \\
\hline 2 & 1536 & 35.9 & 16.2 & 180.9 & 233.0 \\
\hline 3 & 1701 & 18.9 & 81.4 & 136.6 & 237.0 \\
\hline 4 & 1701 & 33.6 & 21.9 & 149.0 & 204.5 \\
\hline 5 & 1835 & 22.2 & 41.5 & 122.2 & 185.9 \\
\hline 6 & 1835 & 24.8 & 35.4 & 105.7 & 165.8 \\
\hline 7 & 1966 & 16.3 & 52.8 & 172.4 & 241.5 \\
\hline 8 & 1966 & 28.7 & 29.8 & 156.2 & 214.8 \\
\hline \multicolumn{2}{|c|}{ Average } & 25.7 & 38.6 & 146.9 & 211.2 \\
\hline
\end{tabular}

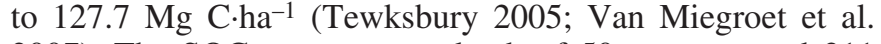
2007). The SOC storage to a depth of $50 \mathrm{~cm}$ averaged 211 $\mathrm{Mg} \cdot \mathrm{ha}^{-1}$, ranging from 166 to $241.5 \mathrm{Mg} \cdot \mathrm{ha}^{-1}$, which represented $54 \%$ of total ecosystem $\mathrm{C}$ storage (Table 2). Average C storage in the spruce-fir forest floor was $25.7 \mathrm{Mg} \mathrm{C} \cdot \mathrm{ha}^{-1}$, ranging from 16.3 to $35.9 \mathrm{Mg} \mathrm{C} \cdot \mathrm{ha}^{-1}$, and accounted for $12 \%$ of total soil organic $\mathrm{C}$ storage to a depth of $50 \mathrm{~cm}$. The A-horizon to $15 \mathrm{~cm}$ averaged $38.6 \mathrm{Mg} \mathrm{C} \cdot \mathrm{ha}^{-1}$, ranging from 16.2 to $52 \mathrm{Mg} \mathrm{C} \cdot \mathrm{ha}^{-1}$, and accounted for $18 \%$ of the total soil organic C. Between 15 and $50 \mathrm{~cm}$ depth, an additional $146.9 \mathrm{Mg} \mathrm{C} \cdot \mathrm{ha}^{-1}$ was stored in the mineral soil, ranging from 105.7 to $180.9 \mathrm{Mg} \mathrm{C} \cdot \mathrm{ha}^{-1}$ (Table 2). In some sampling points, we were not able to take soil cores to a depth of $50 \mathrm{~cm}$, consistent with earlier observations of a relatively shallow soil (Johnson et al. 1991; Van Miegroet et al. 2001) because of a layer of dense subsurface gravel and fractured rock documented by Feldman et al. (1991).

Our total soil $\mathrm{C}$ pool sizes are higher than the mean calculated by Miller et al. (2004) for well-drained soils in southwestern Virginia $\left(112 \mathrm{Mg} \cdot \mathrm{ha}^{-1}\right)$, but closely correspond to the average of $201 \mathrm{Mg} \mathrm{C} \cdot \mathrm{ha}^{-1}$ estimated by Kern (1994) for Haplumbrepts, the dominant soil classification in the spruce-fir. They are similar to the worldwide average for wet boreal forests (Post et al. 1982; Callesen et al. 2003). Forest floor $\mathrm{C}$ pools are at the low end of estimates for other montane conifer forests in North America (Van Miegroet et al. 2007), and fall in between the worldwide averages for temperate and cold temperate coniferous forests (Cole and Rapp 1982; Vogt et al. 1986). Our forest floor C estimates are lower, and soil $\mathrm{C}$ estimates are higher compared with other studies in the Southern Appalachians. Johnson and Lindberg (1992) estimated that the forest floor and mineral soil (0-49 and 0-64 cm) contained, respectively, 41 and $112 \mathrm{Mg} \mathrm{C} \cdot \mathrm{ha}^{-1}$, while Garten et al. (1999) reported an average of $35 \mathrm{Mg} \mathrm{C} \cdot \mathrm{ha}^{-1}$ for forest floor $\mathrm{C}$ and an average of $72 \mathrm{Mg} \mathrm{C} \cdot \mathrm{ha}^{-1}$ for mineral soil C storage $(0-30 \mathrm{~cm})$ in two high-elevation spruce-fir plots. The lack of consistent results from southern Appalachian spruce-fir zone studies may be attributable to sampling methodology and because it is sometimes difficult to discern purely organic forest floor from organic-rich mineral soils, especially in ecosystems like the spruce-fir where mixing of layers has occurred (Federer 1982; Ryan et al. 1992).

Contrary to our hypothesis, total $\mathrm{C}$ storage in the soil showed no relationship with elevation; if any trend was present, it indicated lowest soil $\mathrm{C}$ storage in the mid-elevation plots relative to the lower- and higher-elevations plots
Fig. 3. Relationship between forest floor carbon content and elevation; bars represent standard deviation $(n=2)$ per elevation band.

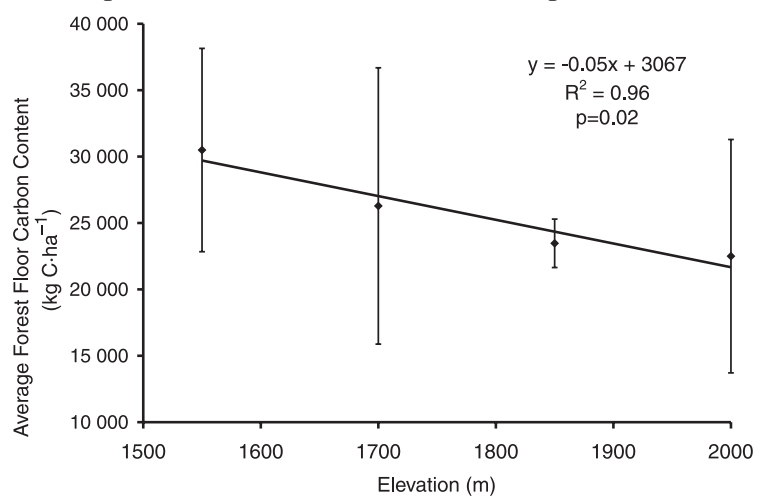

(Table 2). When plots were combined into elevation bands, only average forest floor $\mathrm{C}$ exhibited a significant negative correlation with elevation $\left(R^{2}=0.96, p=0.02 ; y=-0.05 x+\right.$ 3067) (Fig. 3). This pattern in forest floor $\mathrm{C}$ accumulation was likely driven by a decline in overstory production and litterfall with elevation. Indeed, average litterfall inputs for lower-elevation NAPAP plots were $1790 \mathrm{~kg} \mathrm{C} \cdot \mathrm{ha}^{-1} \cdot$ year $^{-1}$ compared with a mean of $1500 \mathrm{~kg} \mathrm{C} \cdot \mathrm{ha}^{-1} \cdot \mathrm{year}^{-1}$ for the mid-elevation NDW plots, and only $1000 \mathrm{~kg} \mathrm{C} \cdot \mathrm{ha}^{-1} \cdot$ year $^{-1}$ in the upper-elevation NAPAP plots. Litterfall corresponded to average live basal area (LBA) of $60 \mathrm{~m}^{2} \cdot \mathrm{ha}^{-1}$ in the lower NAPAP plots, $37 \mathrm{~m}^{2} \cdot \mathrm{ha}^{-1}$ in the NDW plots, and $52 \mathrm{~m}^{2} \cdot \mathrm{ha}^{-1}$ in the upper NAPAP plots (Table 2). Differences in litterfall alone could not explain forest floor accumulation patterns, as forest floor $\mathrm{C}$ pools at the lower elevation were only 1.4 times those of the upper-elevation plots, despite almost double the amount of $\mathrm{C}$ input via litterfall. This suggests differences in $\mathrm{C}$ turnover rates with elevation.

\section{Litter decomposition rates}

Overall, decomposition rates of spruce needles were relatively high, with only $43 \%$ of substrate remaining after 3 years (Fig. 4; Table 3). Decomposition rates were always lower over winter months (October-June) corresponding to the relative plateau of decomposition between 6 and 12 months and between 18 and 24 months. Decomposition rates did not vary consistently with elevation, and plot differences were not statistically significant at all measurement dates. Throughout the 3 year study, the lowest decomposition rates were measured at the upper-elevation plots, consistent with lower mean temperature; and the highest decomposition 
Fig. 4. Relative weight loss of decomposing litter over a 3 year period by elevation band.

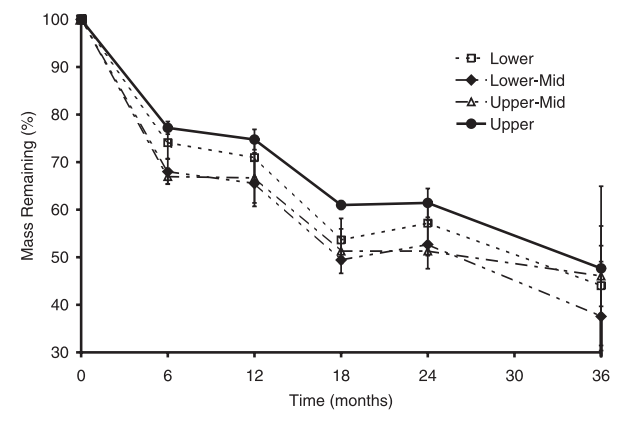

rates were measured in the mid-elevation plots (Fig. 4; Table 3). However, there were never statistically significant differences between the lower- and upper-elevation plots or between the lower-mid and upper-mid elevation plots. At the end of the 3 years, differences among elevation bands had dissipated, partly because of greater within-plot variability (Fig. 4).

Litter decay constants (k) (Olson 1963; Swift et al. 1979), calculated for each elevation band based on 3 years of decomposition (mass loss) data also supported slower decomposition in the upper-elevation band, with the lowest $k=$ $0.0231 \cdot$ year $^{-1}$, followed by $k=0.0272 \cdot$ year $^{-1}$ in the lowerelevation band. The highest decay constants were calculated for the lower-mid and upper-mid elevation bands, with $k=0.0326 \cdot$ year $^{-1}$ and $0.0301 \cdot$ year $^{-1}$, respectively. While not calculated directly, $k$ values for $\mathrm{C}$ loss would have been quite similar, as $\mathrm{C}$ concentrations remainded fairly stable during decomposition (average 52\% between 6 and 24 months, average $50 \%$ at 36 months).

The overall mass loss estimates in our study closely parallel those published for the initial 3 years in the cool temperate climate forest site (Port McNeill, British Columbia) within the long-term Canadian Intersite Decomposition Experiment (CIDET), where only $47 \%$ of the mass of all litter types remained after the 3 years (Moore et al. 1999), similar to the $43 \%$ observed in our study. Trofymow et al. (2002) published mass loss results from the same study after 6 years, with $35 \%$ of the mass of all litter types remaining in the cool temperature climate. This indicates a progressive decline in decomposition rates over time, and suggests that a 3 year study is likely to capture major trends and differences in litter turnover. Our estimates of spruce needle decomposition rates are similar to the first-year values published by Johansson (1995) for spruce needle along a climatic transect from the Arctic Circle in Scandinavia to northern continental Europe (81\%-66\% mass remaining after 1 year), but higher than those reported by Gholz et al. (2000) for pine (Pinus resinosa Soland.) leaves in five temperate coniferous forests in North America as part of the Long-Term Intersite Decomposition Experiment (LIDET) $(82 \%$ and $46 \%$ of pine needle mass remaining after 1 and 5 years, respectively).

No direct correlation between soil temperature and decomposition rates was found in our study, although the cooler upper-elevation plots consistently had lower rates of decomposition. This suggests that other factors besides temperature may have influenced $\mathrm{C}$ turnover at our sites, such as precipitation input and soil moisture; litter quality (e.g., lignin content) or chemistry (e.g., $\mathrm{N}$ content). In the CIDET study, decomposition was strongly related to mean annual temperature and precipitation accounting for $72 \%-87 \%$ of the variance (Moore et al. 1999). Gholz et al. (2000) also found significant positive correlations between mean annual temperature and litter decomposition rates. No significant correlation between mass loss of spruce needle litter and climate factors was reported by Johansson (1995). However, in that study, mass loss was significantly correlated with substrate quality factors ( $\mathrm{Mn}$ and lignin concentrations).

\section{Forest floor mean residence time}

Overall mean residence time (MRT) of the forest floor across the 16 spruce-fir plots (four NAPAP, 12 NDW) was 17 years, ranging from 7 to 23 years. The forest floor had an average MRT of 17 years in lower-elevation NAPAP plots; 14 years in the mid-elevation NDW plots; and 22 years in the upper NAPAP plots. This elevation pattern was consistent with findings from the litterbag study, with the highest turnover in the mid-elevation plots and lowest turnover in the cooler upper plots. To analyze correlations between soil temperature and MRT, the MRT of the 12 NDW plots ("litterfall plots", Fig. 1) was averaged to represent three elevation bands, with corresponding soil temperature data collected along an elevation transect within the watershed ("temperature transect", Fig. 1) also averaged by elevation band. Individual plot-level data were used for the two lower-elevation and upper-elevation NAPAP plots, because plot-specific soil temperature data were available. Across this combined data set, MRT was negatively correlated with MAST (Fig. 5), and $\operatorname{ADD}\left(R^{2}=0.85, p=0.08 ; y=-0.282 x+\right.$ 46.59), indicating that the observed differences in forest floor $\mathrm{C}$ accumulation with elevation (Fig. 3) reflected the differences in litterfall (decline with elevation; Van Miegroet et al. 2007) modified by organic matter turnover (slower at higher and cooler sites).

Our calculated MRT values are well within the range of published data for spruce-fir and conifer forests. Garten et al. (1999) estimated average forest floor MRT of highelevation spruce-fir at around 15 years, while Johnson and Lindberg (1992) reported forest floor C inventories for the same area that range from 44000 to $67000 \mathrm{~kg} \mathrm{C} \cdot \mathrm{ha}^{-1}$ and litterfall inputs that range from 885 to $2700 \mathrm{~kg} \mathrm{C} \cdot \mathrm{ha}^{-1} \cdot \mathrm{year}^{-1}$, with corresponding MRT between 16 and 76 years. In the spruce-dominated northern region of Maine, Simmons et al. (1996) estimated MRT of the forest floor to be 11 years. A MRT for the forest floor organic matter was estimated at 17 years for temperate coniferous forests (Cole and Rapp 1982), and at 14 years for cold temperate needleleaf evergreen forests (Vogt et al. 1986) and cool temperate forests (Admundson 2001). The average decomposition rate of forest floor C (1/MRT) is $0.0588 \cdot$ year $^{-1}$, close to the decay constants $\left(k=0.0583 \cdot\right.$ year $^{-1}$ and $0.0610 \cdot$ year $\left.^{-1}\right)$ derived by Garten et al. (1999) for unprotected SOC at two high-elevation spruce-fir sites in the GSMNP.

\section{Soil respiration}

Mean annual soil respiration across the eight plots was $1460 \mathrm{~kg} \mathrm{C} \cdot \mathrm{ha}^{-1} \cdot$ year $^{-1}$, ranging from 1020 to $1830 \mathrm{~kg} \mathrm{C} \cdot \mathrm{ha}^{-1} \cdot \mathrm{year}^{-1}$ (Table 4). Annual rates were posi- 
Table 3. Analysis of variance of needle mass remaining over 3 years of decomposition.

\begin{tabular}{|c|c|c|c|c|c|c|}
\hline Month & $p$ & Mean mass remaining $(\%)^{*}$ & df & MS & $n$ & Elevation band \\
\hline \multirow[t]{4}{*}{6} & 0.03 & $74.10 \pm 3.36 \mathrm{ab}$ & 3 & 48.2 & 2 & Lower \\
\hline & & $60.95 \pm 2.64 c$ & & & 2 & Lower-mid \\
\hline & & $68.00 \pm 1.52 b c$ & & & 2 & Upper-mid \\
\hline & & $77.21 \pm 1.33 \mathrm{a}$ & & & 2 & Upper \\
\hline \multirow[t]{4}{*}{12} & 0.26 & $70.93 \pm 4.12$ & 3 & 35.7 & 2 & Lower \\
\hline & & $65.51 \pm 4.82$ & & & 2 & Lower-mid \\
\hline & & $66.68 \pm 5.26$ & & & 2 & Upper-mid \\
\hline & & $74.75 \pm 2.14$ & & & 2 & Upper \\
\hline \multirow[t]{4}{*}{18} & 0.08 & $53.64 \pm 4.53 \mathrm{ab}$ & 3 & 51.4 & 2 & Lower \\
\hline & & $49.42 \pm 0.71 b$ & & & 2 & Lower-mid \\
\hline & & $51.29 \pm 4.67 \mathrm{~b}$ & & & 2 & Upper-mid \\
\hline & & $60.98 \pm 0.90 \mathrm{a}$ & & & 2 & Upper \\
\hline \multirow[t]{4}{*}{24} & 0.14 & $57.17 \pm 4.07$ & 3 & 42.3 & 2 & Lower \\
\hline & & $51.30 \pm 5.09$ & & & 2 & Lower-mid \\
\hline & & $52.68 \pm 0.95$ & & & 2 & Upper-mid \\
\hline & & $61.43 \pm 3.03$ & & & 2 & Upper \\
\hline \multirow[t]{4}{*}{36} & 0.86 & $46.65 \pm 12.56$ & 3 & 39.3 & 2 & Lower \\
\hline & & $37.56 \pm 11.52$ & & & 2 & Lower-mid \\
\hline & & $44.02 \pm 6.37$ & & & 2 & Upper-mid \\
\hline & & 47. $66 \pm 17.28$ & & & 2 & Upper \\
\hline
\end{tabular}

*Means with different letters are significantly different at $p \leq 0.1$.

Fig. 5. Relationship between calculated mean residence time of the forest floor and average annual soil temperature. Diamonds, individual National Acid Precipitation Assessment Program (NAPAP) plots; triangles, Noland Divide Watershed (NDW) elevation bands $(n=4)$. Bars represent standard deviation $(n=4)$ per elevation band in NDW.

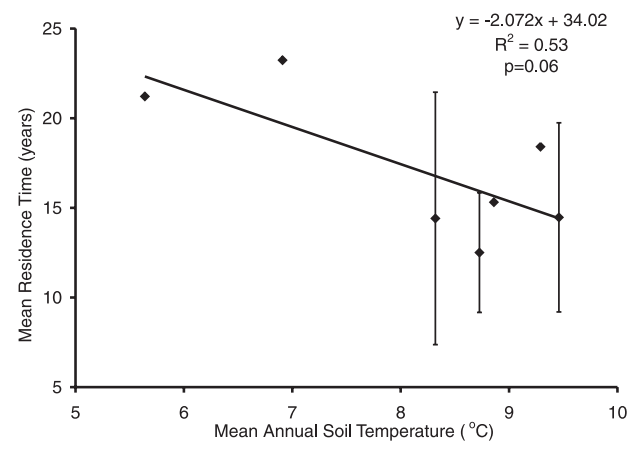

tively correlated with corresponding plot soil temperature regime expressed as MAST $\left(R^{2}=0.44, p=0.07 ; y=\right.$ $0.003 x+2.97$ ) or ADD (Fig. 6).

In this study, average respiration rates during the fall period were higher than summer respiration rates $\left(5.15 \mathrm{~kg} \mathrm{CO}_{2^{-}}\right.$ $\mathrm{C} \cdot \mathrm{ha}^{-1} \cdot$ day $^{-1}$ in summer versus $5.23 \mathrm{~kg} \mathrm{CO}$-C $\cdot \mathrm{ha}^{-1} \cdot$ day $^{-1}$ in fall), even though soil temperatures in summer were 2$3{ }^{\circ} \mathrm{C}$ higher. This is counter to the accepted norm that $\mathrm{C}$ dynamics are mostly temperature driven. The higher $\mathrm{CO}_{2}$ efflux rates in fall may be due to input of a fresh decomposable $\mathrm{C}$ source with litterfall. It may also reflect the confounding effect of other factors, such as substrate moisture content and (or) quality. Soil temperature and moisture often interact to control the rate of soil respiration, but their effect is difficult to separate, as their interaction may be temporally and spatially variable and possibly sitespecific (e.g., Davidson et al. 1998). Our data do suggest that soil temperature may not be the sole driver for soil $\mathrm{CO}_{2}$ efflux in this system.

Annual $\mathrm{CO}_{2}$ efflux rates for the spruce-fir, even when corrected for systematic methodological bias (2600$3900 \mathrm{C} \cdot$ ha $^{-1} \cdot$ year $^{-1}$, Van Miegroet et al. 2007), are lower than the values for some common temperate coniferous forests reported by Kane et al. (2003) (5000-7000 kg C.ha-1.year $\left.{ }^{-1}\right)$, Rustad et al. (2001) (3000-12000 kg C $\left.\cdot \mathrm{ha}^{-1} \cdot \mathrm{year}^{-1}\right)$, and Davidson et al. (2002) (6500-9900 kg C. ha ${ }^{-1} \cdot$ year $\left.^{-1}\right)$. They are more comparable to $\mathrm{CO}_{2}$ efflux rates for spruce in Alaska summarized by Raich and Tufekcioglu (2000) (3100 kg C $\cdot$ ha $^{-1}$ year $^{-1}$ ), and Vogel et al. (2005) (3100-6000 kg C.ha ${ }^{-1} \cdot$ year $^{-1}$ ). One potential reason for the difference between our results and published annual respiration rates is that winter $\mathrm{CO}_{2}$ efflux rates were estimated from summer rates and temperatures, assuming a $Q_{10}=2$, rather than being measured directly. The actual $Q_{10}$ factor can vary significantly across a wide range of climatic conditions (Schleser 1982; Raich and Schlesinger 1992; Peterjohn et al. 1994), ranging from 1.6 to 3.2 (Schlesinger 1977; Singh and Gupta 1979; Kirschbaum 1995; Grogan et al. 2000). Applying this range of possible $Q_{10}$ values to our data would have yielded daily winter rates between $1.87\left(Q_{10}=3.2\right)$ and $3.42 \mathrm{~kg} \cdot \mathrm{ha}^{-1} \cdot \mathrm{d}^{-1}$ $\left(Q_{10}=1.6\right)$, compared with the $2.82 \mathrm{~kg} \cdot \mathrm{ha}^{-1} \cdot \mathrm{d}^{-1}\left(Q_{10}=2\right)$, used in our flux calculation. This would have translated into annual $\mathrm{CO}_{2}$ efflux rates that were either $7.5 \%$ higher $\left(Q_{10}=1.6\right)$ or $12 \%$ lower $\left(Q_{10}=3.2\right)$ than our current estimates. Total belowground $\mathrm{C}$ allocation (TBCA) in this system has been estimated at $\sim 1700 \mathrm{~kg} \mathrm{C} \cdot \mathrm{ha}^{-1} \cdot \mathrm{year}^{-1}$ (possibly as high as $2100 \mathrm{~kg} \mathrm{C} \cdot \mathrm{ha}^{-1} \cdot \mathrm{year}^{-1}$ ), assuming belowground steady state conditions (Van Miegroet et al. 2007). The latter assumption seems reasonable, given the mature stage of the forest and the shallow soil depth $(<50 \mathrm{~cm})$, which allows for limited expansion of the roots. Using an average methodological correction factor of $47 \%$ to our total annual soil $\mathrm{CO}_{2}$ efflux rates (Knoepp and Vose 2002), and 
Table 4. Seasonal soil respiration rates.

\begin{tabular}{|c|c|c|c|c|}
\hline Plot & 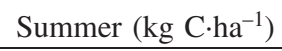 & Fall $\left(\mathrm{kg} \mathrm{C} \cdot \mathrm{ha}^{-1}\right)$ & Winter $\left(\mathrm{kg} \mathrm{C} \cdot \mathrm{ha}^{-1}\right)^{*}$ & Annual $\left(\mathrm{kg} \mathrm{C} \cdot \mathrm{ha}^{-1} \cdot \mathrm{year}^{-1}\right)$ \\
\hline 1 & $651 \pm 183^{\dagger}$ & $567 \pm 95$ & 610 & 1828 \\
\hline 2 & $586 \pm 91$ & $500 \pm 268$ & 565 & 1650 \\
\hline 3 & $618 \pm 228$ & $411 \pm 177$ & 594 & 1624 \\
\hline 4 & $362 \pm 124$ & $313 \pm 19$ & 343 & 1018 \\
\hline 5 & $591 \pm 235$ & $318 \pm 4$ & 510 & 1419 \\
\hline 6 & $589 \pm 285$ & $332 \pm 82$ & 558 & 1478 \\
\hline 7 & $448 \pm 139$ & $404 \pm 58$ & 362 & 1214 \\
\hline 8 & $574 \pm 155$ & $334 \pm 192$ & 534 & 1442 \\
\hline Average & 552 & 397 & 510 & 1459 \\
\hline
\end{tabular}

Fig. 6. Relationship between mean annual respiration and soil heat index as expressed by annual degree-days over $5{ }^{\circ} \mathrm{C}$.

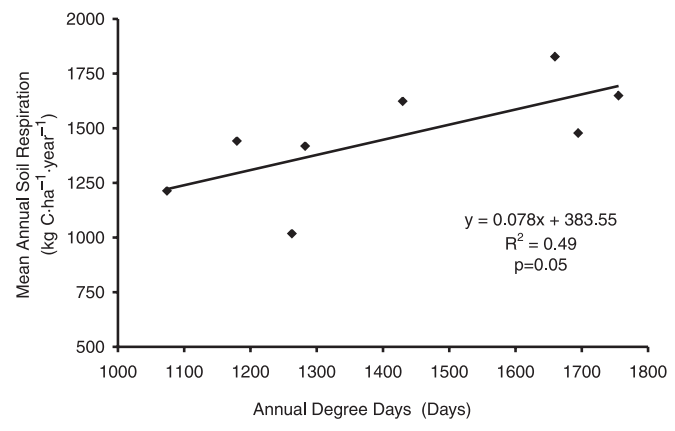

above TBCA values (Van Miegroet et al. 2007), annual heterotrophic respiration rates are estimated at $\sim 1450 \mathrm{~kg}$ $\mathrm{C} \cdot \mathrm{ha}^{-1} \cdot$ year $^{-1}$ or lower. This corresponds to $\sim 45 \%$ of the total soil $\mathrm{CO}_{2}$ efflux, compared with $\sim 30 \%$ reported for mature boreal and cold temperate forests in Bond-Lamberty et al. (2004). Our estimate of heterotrophic respiration closely resembles average annual litterfall C inputs of $1400 \pm$ $280 \mathrm{~kg} \mathrm{C} \cdot \mathrm{ha}^{-1} \cdot$ year $^{-1}$ for the NDW (5 year mean) and $1200 \pm 520 \mathrm{~kg} \mathrm{C} \cdot \mathrm{ha}^{-1} \cdot$ year $^{-1}$ for the four NAPAP plots $(2$ year mean). It substantiates near steady-state conditions of the forest floor (inputs equal outputs) and suggests that heterotrophic $\mathrm{C}$ efflux is mainly derived from the decomposition of fresh litter, conditions which underly our calculation of forest floor MRT.

\section{Conclusions}

Significant differences in temperature existed along the elevation gradient in the high-elevation spruce-fir, providing us with an opportunity to test temperature as a driver of soil C storage and dynamics. As predicted, indices of the temperature regime, including mean annual soil temperature and annual degree-days, were inversely correlated with elevation. Differences in soil temperature along the elevation gradient resulted in significant differences in forest floor $\mathrm{C}$ pools, litter decomposition rates, forest floor mean residence time, and soil respiration. However, SOC pool and flux patterns did not always follow clean and consistent trends with elevation, possibly reflecting confounding factors such as stand structure and growth patterns (Van Miegroet et al. 2007), soil moisture, and litter quality. Nevertheless, the SOC dynamics in this spruce-fir ecosystem appeared re- sponsive to soil temperatures, and soil warming will likely result in greater $\mathrm{CO}_{2}$ releases because of accelerated turnover of the C-rich soil substrates.

The mid-elevation plots consistently emerged as having the most rapid SOC turnover, also reflected by lower total SOC storage. The cooler upper-elevation plots were consistently characterized by slower $\mathrm{C}$ turnover, indicated by lower litter decomposition rates, lower soil respiration rates, and higher mean residence times of forest floor C. Laboratory incubations further indicated that organic and mineral horizons in the upper-elevation band contained more labile $\mathrm{C}$ than lower- and mid-elevation sites (Tewksbury 2005). Larger residual active $\mathrm{C}$ pools in the upper elevation suggests incomplete decomposition, limited by cooler temperatures, compared with the depletion of active $\mathrm{C}$ pools in the lower elevations where decomposition rates are generally higher. A clear temperature limitation of $\mathrm{C}$ dynamics at the highest elevations combined with resultant SOC quality shifts towards higher concentrations of active $\mathrm{C}$, thus suggests that higher-elevation zones in these ecosystem sites may experience the largest impacts of future warming scenarios, and may in fact become net sources of $\mathrm{CO}_{2}$, if soil $\mathrm{C}$ dynamics in the lower elevations are indicative of how future climatic trajectories may affect upper elevations. Midand lower-elevation sites would appear less sensitive to global warming. At this point it is still unclear how the concurrent change in potentially confounding factors, such as soil moisture and litter quality, may affect future temperature responses of this ecosystem, or how long temperaturedriven $\mathrm{C}$ release pulses could be sustained.

An additional confounding factor in predicting SOC response to global change is that in addition to warming, there may be a change in precipitation form, timing, and amount (Weltzin et al. 2003). Many high-elevation forests are located in areas that receive substantial amounts of precipitation as snow, and the reduction or disappearance of an insulating snow pack may affect soil $\mathrm{C}$ turnover in winter (Bubier et al. 2002). In the southern Appalachians, however, a very thick and persistent snow pack rarely accumulates throughout the winter, soils are often frozen, and $\mathrm{C}$ dynamics are generally slow in winter. Changes in snow accumulation and retention may therefore have less impact on overall $\mathrm{C}$ dynamics than future changes in the soil temperature and moisture regime during summer, and especially in fall when fresh needle fall stimulates decomposer activity. While this 
elevation gradient is not a perfect proxy for future climate change scenarios, it nevertheless provides us with some useful insights into patterns of SOC accumulation and dynamics that help identify those areas that are most likely to respond to changes in global climate.

\section{Acknowledgements}

We graciously thank Alan Mays, Larry Shelton, Anita Rose, and Suzanne Fisher from the Tennessee Valley Authority (TVA) for all of their logistical assistance; Michael Griffiths, Bryan Drew, Faye Tewksbury, Patrick Moore, and Lisa Moore for their help in the field; numerous students in the Utah State University Forest Soils Lab for their help in preparing and processing field samples. We also thank TVA and the Environmental Protection Agency for the use of the forest inventory data sets; and Mike Ebinger and Patrick Moore for their assistance in creating the GIS map. Funding for data collection was provided by the USDA National Research Initiative Competitive Grants Program (grant 97-35101-4314 to Utah State University), the USGS Biological Research Division (cooperative agreement 1434 HQ97-RV-01555 RWO27 and RWO34 to the Utah Cooperative Fish and Wildlife Research Unit), and Tennessee Valley Authority's Public Power Institute. UAES Publication 7784, Utah Agricultural Experiment Station, Utah State University, Logan, Utah 84322-4810.

\section{References}

Admundson, R. 2001. The carbon budget in soils. Annu. Rev. Earth Planet. Sci. 29: 535-562.

Albritton, D.L., Meira Filho, L.G., Cubasch, U., Dai, X., Ding, Y., Griggs, D.J., Hewitson, B., Houghton, J.T., Isaksen, I., Karl, T., McFarland, M., Meleshko, V.P., Mitchell, J.F.B., Noguer, M., Nyenzi, B.S., Oppenheimer, M., Penner, J.E., Pollonais, S., Stocker, T., and Trenberth, K.E. 2001. Technical summary of the Working Group 1 Report. In Climate change 2001: The scientific basis. Contribution of Working Group I to the Third Assessment Report of the Intergovernmental Panel on Climate Change. Edited by R.A. Houghton. Cambridge University Press, Cambridge. pp. 21-83.

Alexander, M. 1977. Introduction to soil microbiology. 2nd ed. John Wiley \& Sons, Inc., Indianapolis, Ind.

Barker, M., Van Miegroet, H., Nicholas, N.S., and Creed, I.F. 2002. Variation in overstory nitrogen uptake in a small, highelevation southern Appalachian spruce-fir watershed. Can. J. For. Res. 32: 1741-1752. doi:10.1139/x02-098.

Blake, G.R., and Hartge, K.H. 1986. Bulk density. In Methods of soil analysis. Part 1. Physical and mineralogical methods. Edited by A. Klute. Agronomy 9. Agronomy Society of America, Madison, Wisc. pp. 363-375.

Bolstad, P.V., and Vose, J.M. 2001. The effects of terrain position and elevation on soil organic carbon in the Southern Appalachians. In Assessment methods for soil carbon. Edited by R. Lal. CRC/Lewis Publ., Boca Raton, Fla. pp. 4-51.

Bond-Lamberty, B., Wang, C., and Gower, S.T. 2004. A global relationship between the heterotrophic and autotrophic components of soil respiration? Glob. Change Biol. 10: 1756-1766. doi:10.1111/j.1365-2486.2004.00816.x.

Bubier, J., Crill, P., and Mosedale, A. 2002. Net ecosystem $\mathrm{CO}_{2}$ exchange measured by autochambers during the snow-covered season at a temperate peatland. Hydrol. Process. 16: 3667-3682. doi:10.1002/hyp.1233.
Callesen, I., Liski, J., Raulund-Rasmussen, K., Olsson, M.T., TauStrands, L., Vesterdal, L., and Westman, C.J. 2003. Soil carbon stores in Nordic well-drained forest soils-relationship with climate and texture class. Glob. Change Biol. 9: 358-370. doi:10. 1046/j.1365-2486.2003.00587.x.

Cole, D.W., and Rapp, M. 1982. Elemental cycling in forest ecosystems. In Dynamic properties of forest ecosystems. Edited by D.E. Reichle. Cambridge University Press, Cambridge. pp. 341-409.

Cropper, W.P., Ewel, K.C., and Raich, J.W. 1985. The measurement of soil $\mathrm{CO}_{2}$ evolution in situ. Pedobiologia (Jena), 28: 35-40.

Davidson, E.A., and Janssens, I.A. 2006. Temperature sensitivity of soil carbon decomposition and feedbacks to climate change. Nature (London), 440: 165-173. doi:10.1038/nature04514. PMID: 16525463.

Davidson, E.A., Belk, E., and Boone, R.D. 1998. Soil water content and temperature as independent or confounded factors controlling soil respiration in a temperate mixed hardwood forest. Glob. Change Biol. 4: 217-227. doi:10.1046/j.1365-2486.1998. 00128.x.

Davidson, E.A., Savage, K., Bolstad, P., Clark, D.A., Curtis, P.S., Ellsworth, D.S., Hanson, P.J., Law, B.E., Luo, Y., Pregitzer, K.S., Randolph, J.C., and Zak, D. 2002. Belowground carbon allocation in forests estimated from litterfall and IRGA-based soil respiration measurements. Agric. For. Meteorol. 113: 39-51. doi:10.1016/S0168-1923(02)00101-6.

Dull, C.W., Ward, J.E., Brown, H.D., Ryan, G.W., Clerke, W.H., and. Uhler, R.J. 1988. Evaluation of spruce and fir mortality in the southern Appalachian mountains. USDA For. Serv. Res. Pap. R8-PR 13.

Federer, C.A. 1982. Subjectivity in the separation of organic horizons of the forest floor. Soil Sci. Soc. Am. J. 46: 1090-1093.

Feldman, S.B., Zelanzy, L.W., and Baker, J.C. 1991. High elevation forest soils of the Southern Appalachains I: distribution of parent materials and soil-landscape relationships. Soil Sci. Soc. Am. J. 55: 1629-1637.

Fernandez, I.J. 1992. Characterization of Eastern U.S. spruce-fir soils. In Ecology and decline of red spruce in the Eastern United States. Edited by C. Eagar and M.B. Adams. Springer-Verlag, New York. pp. 40-63.

Garten, C.T., and Van Miegroet, H. 1994. Relationship between site nitrogen dynamics and natural ${ }^{15} \mathrm{~N}$ abundance in plant foliage from the Great Smoky Mountains National Park. Can. J. For. Res. 24: 1636-1645.

Garten, C.T., Post, W.M., III, Hanson, P.J., and Cooper, L.W. 1999. Forest soil carbon inventories and dynamics along an elevation gradient in the southern Appalachian Mountains. Biogeochemistry, 45: 115-145.

Garten, C.T., Cooper, L.W., Post, W.M., III, and Hanson, P.J. 2000. Climate controls on forest soil carbon isotope ratios in the southern Appalachian mountains. Ecology, 81: 1108-1119. doi: $10.2307 / 177182$.

Gholz, H.L., Smitherman, S.M., Wedin, D.A., Harmon, M.E., and Parton, W.J. 2000. Long-term dynamics of pine and hardwood litter in contrasting environments: toward a global model of decomposition. Glob. Change Biol. 6: 751-765. doi:10.1046/j. 1365-2486.2000.00349.x.

Giardina, C.P., and Ryan, M.G. 2000. Evidence that decomposition rates of organic carbon in mineral soil do not vary with temperature. Nature (London), 404: 858-861. doi:10.1038/35009076. PMID: 10786789.

Grogan, P., Baar, J., and Bruns, T.D. 2000. Below-ground ectomycorrhizal community structure in a recently burned bishop pine forest. J. Ecol. 88: 1051-1062. doi:10.1046/j.1365-2745.2000. 00511.x 
Johansson, M.B. 1995. The chemical composition of needle and leaf litter from Scots pine, Norway spruce and white birch in Scandinavian forests. Forestry, 68: 49-62. doi:10.1093/forestry/ 68.1.49.

Johnson, D.W., and Lindberg, S.E. (Editors). 1992. Atmospheric deposition and nutrient cycling in forest ecosystems: a synthesis of the Integrated Forest Study. Springer-Verlag, New York.

Johnson, D.W., Van Miegroet, H., Lindberg, S.E., Harrison, R.B., and Todd, D.E. 1991. Nutrient cycling in red spruce forests of the Great Smoky Mountains. Can. J. For. Res. 21: 769-787.

Joslin, J.D., Kelly, J.M., and Van Miegroet, H. 1992. Soil chemistry and nutrition of North American spruce-fir stands: Evidence for recent change. J. Environ. Qual. 21: 12-30.

Kane, E.S., Pregitzer, K.S., and Burton, A.J. 2003. Respiration along environmental gradients in Olympic National Park. Ecosystems (N.Y. Print), 6: 326-335. doi:10.1007/s10021-0020115-7.

Kelly, J.M., and Mays, P.A. 1989. Physical and chemical characteristics of the rooting zone in southeastern spruce-fir soils. Soil Sci. Soc. Am. J. 53: 1248-1255.

Kern, J.S. 1994. Spatial patterns of soil organic carbon in the contiguous United States. Soil Sci. Soc. Am. J. 58: 439-455.

King, P.B., and Stupka, A. 1950. The Great Smoky Mountains: their geology and natural history. Sci. Mon. 71: 31-43.

Kirschbaum, M.U.F. 1995. The temperature dependence of soil organic matter decomposition, and the effect of global warming on soil organic storage. Soil Biol. Biochem. 27: 753-760. doi:10. 1016/0038-0717(94)00242-S.

Kirschbaum, M.U.F. 2000. Will changes in soil organic carbon act as a positive or negative feedback on global warming? Biogeochemistry, 48: 21-51. doi:10.1023/A:1006238902976.

Knoepp, J.D., and Vose, J.M. 2002. Quantitative comparison of in situ soil $\mathrm{CO}_{2}$ flux measurement methods. USDA For. Serv. Res. Pap. SRS-28.

Knorr, W., Prentice, I.C., House, J.I., and Holland, E.A. 2005. Long-term sensitivity of soil carbon turnover to warming. Nature (London), 433: 298-302. doi:10.1038/nature03226. PMID: 15662420.

Liski, J., Ilvesniemi, H., Mäkelä, A., and Westman, C.J. 1999. $\mathrm{CO}_{2}$ emissions from soil in repsonse to climatic warming are overestimated: the decomposition of old organic matter is tolerant of temperature. Ambio, 28: 171-174.

Melillo, J.M., Steudler, P.A., Aber, J.D., Newkirk, K., Lux, H., Bowles, F.P., Catricala, C., Magill, A., Ahrens, T., and Morrisseau, S. 2002. Soil warming and carbon-cycle feedbacks to the climate system. Science (Washington, D.C.), 298: 2173-2176. doi:10.1126/science.1074153. PMID:12481133.

Miller, J.O., Galbraith, J.M., and Daniels, W.L. 2004. Soil organic carbon content in frigid southern Appalachian mountain soils. Soil Sci. Soc. Am. J. 68: 194-203.

Moore, T.R., Trofymow, J.A., Taylor, B., Prescott, C., Camire, C., Duschene, L., Fyles, J., Kozak, L., Kranabetter, M., Morrison, I., Siltanen, M., Smith, S., Titus, B., Visser, S., Wein, R., and Zoltai, S. 1999. Litter decomposition rates in Canadian forests. Glob. Change Biol. 5: 75-82. doi:10.1046/j.1365-2486.1998. 00224.x.

Nicholas, N.S., Zedaker, S.M., and Eagar, C. 1992. A comparison of overstory community structure in three southern Appalachian spruce-fir forests. Bull. Torrey Bot. Club, 119: 316-332. doi:10. 2307/2996764.

Nodvin, S.C., Van Miegroet, H., Lindberg, S.E., Nicholas, N.S., and Johnson, D.W. 1995. Acidic deposition, ecosystem processes, and nitrogen saturation in a high elevation southern Ap- palachian watershed. Water Air Soil Pollut. 85: 1647-1652. doi:10.1007/BF00477216.

Olson, J.S. 1963. Energy storage and the balance of producers and decomposers in ecological systems. Ecology, 44: 322-331. doi: $10.2307 / 1932179$.

Pauley, E.F. 1989. Energy storage and the balance of producers and decomposers in ecological systems. M.Sc. thesis, University of Tennessee, Knoxville, Tenn.

Pauley, E.F., Nodvin, S.C., Nicholas, N.S., Rose, A.K., and Coffey, T.B. 1996. Vegetation, biomass, and nitrogen pools in a sprucefir forest of the Great Smoky Mountains National Park. Bull. Torrey Bot. Club, 123: 318-329. doi:10.2307/2996781.

Peterjohn, W.T., Melillo, J.M., and Stuedler, P.A. 1994. Responses of trace gas fluxes and $\mathrm{N}$ availability to experimentally elevated soil temperature. Ecol. Appl. 4: 617-625. doi:10.2307/1941962.

Post, W.M., Emanuel, W.R., Zinke, P.J., and Stangenberger, A.G. 1982. Soil carbon pools and world life zone. Nature (London), 298: 156-159. doi:10.1038/298156a0.

Prichard, S.J., Peterson, D.L., and Hummer, R.D. 2000. Carbon distribution in subalpine forests and meadows of the Olympic Mountains, Washington. Soil Sci. Soc. Am. J. 64: 1834-1845.

Pyle, C., and Schafale, M.P. 1988. Land use history of three spruce-fir forest sites in southern Appalachia. J. Forest History, 32: 4-21.

Raich, J.W., and Schlesinger, W.H. 1992. The global carbon dioxide flux in soil respiration and its relationship to vegetation and climate. Tellus, 44B: 81-99.

Raich, J.W., and Tufekcioglu, A. 2000. Vegetation and soil respiration: Correlations and controls. Biogeochemistry, 48: 71-90. doi:10.1023/A:1006112000616.

Raich, J.W., Bowden, R.D., and Steudler, P.A. 1990. Comparison of two static chamber techniques from determining carbon dioxide efflux from forest soils. Soil Sci. Soc. Am. J. 54: 1754-1757.

Rose, A.K. 2000. Coarse woody debris and nutrient dynamics in a Southern Appalachian spruce-fir forest. M.Sc. thesis, University of Tennessee, Knoxville, Tenn.

Rustad, L.E., Campbell, J.L., Marion, G.M., Norby, R.J., Mitchell, M.J., Hartley, A.E., Cornelissen, J.H.C., and Gurevitch, J. 2001. A meta-analysis of the response of soil respiration, net nitrogen mineralization, and aboveground plant growth to experimental ecosystem warming. Oecologia, 126: 543-562.

Ryan, D.F., Huntington, T.G., and Martin, C.W. 1992. Redistribution of soil nitrogen, carbon, and organic matter by mechanical disturbance during whole-tree harvesting in northern hardwoods. For. Ecol. Manage. 49: 87-99. doi:10.1016/0378-1127(92)90162-3.

SAS Institute, Inc. 2002. SAS user's guide. Statistics. Version 8.2 ed. SAS Institute Inc., Cary, N.C.

Schleser, G.H. 1982. The response of $\mathrm{CO}_{2}$ evolution from soil to global temperature changes. Z. Naturforsch. 37: 287-291.

Schlesinger, W.H. 1977. Carbon balance in terrestrial detritus. Annu. Rev. Ecol. Syst. 8: 51-81. doi:10.1146/annurev.es.08. 110177.000411.

Schlesinger, W.H., and Lichter, J. 2001. Limited carbon storage in soil and litter of experimental forest plots under increased atmospheric $\mathrm{CO}_{2}$. Nature (London), 411: 466-469. doi:10.1038/ 35078060. PMID:11373676.

Shanks, R.E. 1954. Climates of the Great Smoky Mountains. Ecology, 35: 354-361. doi:10.2307/1930098.

Simmons, J.A., Fernandez, I.J., Briggs, R.D., and Delaney, M.T. 1996. Forest floor carbon pools and fluxes along a regional climate gradients in Maine, USA. For. Ecol. Manage. 84: 81-95.

Singh, J.S., and Gupta, S.R. 1979. Plant decomposition and soil respiration in terrestrial ecosystems. Bot. Review, 43: 449-528. 
Swift, M.J., Heal, O.W., and Anderson, J.M. 1979. Decomposition in terrestrial ecosystems. Blackwell Scientific, Oxford, UK.

Tewksbury, C.E. 2005. Soil organic carbon dynamics along a climate gradient in a southern Appalachian spruce-fir forest. M.Sc. thesis, Utah State University, Logan, Utah.

Trofymow, J.A., Moore, T.R., Titus, B., Prescott, C., Morrison, I., Siltanen, M., Smith, S., Fyles, J., Wein, R., Camire, C., Duschene, L., Kozak, L., Kranabetter, M., and Visser, S. 2002. Rates of litter decomposition over 6 years in Canadian forests: influences of litter quality and climate. Can. J. For. Res. 32: 789-804. doi:10.1139/x01-117.

Trumbore, S.E. 2000. Age of soil organic matter and soil respiration: Radiocarbon constraints on belowground $\mathrm{C}$ dynamics. Ecol. Appl. 10: 399-411. doi:10.2307/2641102.

Van Miegroet, H., Johnson, D.W., and Todd, D.E. 1993. Foliar response of red spruce saplings to fertilization with $\mathrm{Ca}$ and $\mathrm{Mg}$ in the Great Smoky Mountains National Park. Can. J. For. Res. 23: 89-95.

Van Miegroet, H., Creed, I.F., Nicholas, N.S., Tarboton, D.G., Webster, K.L., Shubzda, J., Robinson, B., Smoot, J., Johnson, D.W., Lindberg, S.E., Lovett, G., Nodvin, S., and Moore, S. 2001. Is there synchronicity in $\mathrm{N}$ input and out fluxes at the Noland Divide Watershed, a small N-saturated forested catchment in the Great Smoky Mountains National Park. TheScientificWorld, 1 (S2): 480-492.

Van Miegroet, H., Moore, P.T., Tewksbury, C.E., and Nicholas, N.S. 2007. Carbon sources and sinks in high-elevation sprucefir forests in the Southeastern US. For. Ecol. Manage. 238: 249-260.

Vogel, J.G., Valentine, D.W., and Reuss, R.W. 2005. Soil and root respiration in mature Alaskan black spruce forests that vary in soil organic matter decomposition rates. Can. J. For. Res. 35: 161-174. doi:10.1139/x04-159.

Vogt, K.A., Grier, C.C., and Vogt, D.J. 1986. Production, turnover, and nutrient dynamics of above- and belowground detritus of world forests. Adv. Ecol. Res, 15: 303-377.

Vogt, K.A., Vogt, D.J., Palmiotto, P.A., Boon, P., O’Hara, J., and Asbjornsen, H. 1996. Review of root dynamics in forest ecosystems grouped by climate, climatic forest type and species. Plant Soil, 187: 159-219.

Weltzin, J.F., Loik, M.E., Schwinning, S., William, D.G., Fay, P.A., Haddad, B.M., Harte, J., Huxman, T.E., Knapp, A.K., Guanghui, L., Pockman, W.T., Shaw, M.R., Small, E.E., Smith, M.D., Smith, S.D., Tissue, D.T., and Zak, J.C. 2003. Assessing the response of terrestrial ecosystems to potential changes in precipitation. Bioscience, 53: 941-952. doi:10.1641/00063568(2003)053[0941:ATROTE]2.0.CO;2.

White, P.S., and Cogbill, C.V. 1992. Spruce-fir forests of Eastern America. In Ecology and decline of red spruce in the Eastern United States. Edited by C. Eagar and M.B. Adams. SpringerVerlag, New York. pp. 3-39.

Wolfe, J.A. 1967. Forest soil characteristics as influenced by vegetation and bedrock in the spruce-fir zone of the Great Smoky Mountains. Ph.D. dissertation, The University of Tennessee, Knoxville, Tenn.

Zak, D.R., Grigal, D.F., and Ohmann, L.F. 1993. Kinetics of microbial respiration and nitrogen mineralization in Great Lake forests. Soil Sci. Soc. Am. J. 57: 1100-1106.

Zolbrod, A.N., and Peterson, D.L. 1999. Response of high-elevation forests in the Olympic Mountains to climatic change. Can. J. For. Res. 29: 1966-1978. doi:10.1139/cjfr-29-12-1966. 